\title{
Algae, macrofaunal assemblages and temperature: a quantitative approach to intertidal ecosystems of Iceland
}

Received: 08 November 2004/ Revised: 02 June 2005/ Accepted: 08 June 2005/Published online: 19 July 2005

(C) Springer-Verlag and AWI 2005

\begin{abstract}
Algae and the associated macrofauna in two Icelandic intertidal ecosystems under cold and warm influence, respectively, were studied with respect to algae-macrofauna relationships and a possible effect of temperature on community structure. Two sites in Iceland were selected, Sandgerdi ligthhouse $\left(64^{\circ} 8^{\prime} \mathrm{N}\right.$ $22^{\circ} 40^{\prime} \mathrm{W}$ ) on the southwestern coast, and Grimsey Island $\left(66^{\circ} 33^{\prime} \mathrm{N} 18^{\circ} 04^{\prime} \mathrm{W}\right)$, in the north, on the Arctic Circle, where sea temperature is considerably lower $\left(5^{\circ}\right.$ approximately). The biomass of algae and the number of species of algae and macrofauna were higher in Sandgerdi than in Grimsey, and the patterns of diversity, evenness, biomass and abundance also differed between the sites. In the intertidal zone of Sandgerdi, a total of 28 species of algae and 45 species of macrofauna were identified whereas only 16 algal species and 27 macrofaunal species were found in Grimsey. Canonical correspondence analysis (CCA) using algal biomass as the environmental variable were conducted, and revealed significant relationships between algae composition and the associated macrofauna; some macrofauna taxa showed specific trophic or refuge relationships with algal species. According to the CCA, Corallina officinalis showed the highest correlation with macrofaunal assemblages in both study sites. However, correlations between macrofauna and other algae differed between Grimsey and Sandgerdi. The present study, together with additional observations in Greenland waters, shows a general decrease of species richness and diversity towards the north which may primarily be due to the temperature regime.
\end{abstract}

Communicated by H.-D. Franke

F. Espinosa $(\bowtie) \cdot$ J. M. Guerra García

Laboratorio de Biología Marina, Departamento de Fisiología

y Zoología, Facultad de Biología, Universidad de Sevilla,

Avda Reina Mercedes 6, 41012 Sevilla, Spain

E-mail: free@us.es

Fax: + 34-954-233480
Keywords Algae $\cdot$ Macrofauna $\cdot$ Temperature ·

Intertidal $\cdot$ Iceland

\section{Introduction}

The situation of Iceland as a boundary between the warm-boreal zone (Atlantic Ocean influence) and the subarctic zone (Arctic influence) provides an interesting scenery to test the effect of temperature on patterns of biomass and abundance of algae and macrofauna. Previous studies have been conducted in Iceland dealing with benthic algal vegetation (see review by Munda 1991), seasonal changes in the abundance of intertidal algae (Gunnarsson and Ingólfsson 1995), patterns in species composition of rocky shore communities (Hansen and Ingólfsson 1993) and macrofaunal distribution according to temperature (Ingólfsson 1996). However, there are no studies focussing on community structure and interactions among seaweeds, macrofauna and temperature influence from a quantitative point of view.

A detailed descriptive and quantitative approach to intertidal communities is useful to estimate parameters such as productivity and community structure. Ecological studies are frequently based on abundance, diversity or biomass values of the biota (Littler and Murray 1975; Warwick 1986; Warwick et al. 1987; Austen et al. 1989; López-Gappa et al. 1990; Sandulli and De Nicola 1991; Anderlini and Wear 1992; Underwood and Chapman 1996) and may contribute to detect microscale relationships among their units and influences of environmental variables. Furthermore, multivariate analyses allow for an analysis of changes in community structure following the method proposed by Clarke (1993) based on Field et al. (1982).

The present paper deals with the relationships among algae and macrofauna in two intertidal ecosystems under cold and warm influence, respectively, and discusses the possible effects of temperature on community structure. 


\section{Materials and methods}

Study area

Two sites in Iceland were selected for the study, Sandgerdi lighthouse $\left(64^{\circ} 8^{\prime} \mathrm{N} 22^{\circ} 40^{\prime} \mathrm{W}\right)$, near Gardur on the southwestern coast, and Grimsey Island $\left(66^{\circ} 33^{\prime} \mathrm{N}\right.$ $18^{\circ} 04^{\prime} \mathrm{W}$ ) in the north, on the Artic Circle (Fig. 1). Both sites are distant from densely populated and/or industrial areas. Therefore, there are no significant effects of pollution, and community structure at both sites is largely controlled by natural, biological and physical factors. Both localities have a similar gentle slope, and a previous survey has indicated that they are representative of the rocky intertidal habitats of the study sites. This is the first study dealing with the macrofauna of Grimsey Island.

The water temperature on the west and southwest coasts of Iceland is about $5^{\circ}$ warmer than on the north and east coasts (Stefansson 1969) because the former are under the influence of warm Atlantic water (Krauss 1958; Malmberg 1962), while the latter are under arctic influence. Several cold arctic water masses originating at East Greenland progressively cool the Irminger Current (Atlantic water) from west to east, until producing the East Icelandic Current (Stefánsson 1962). So, a conspicuous hydrographic limit is found in Northwest Iceland, due to the diminished influx of Atlantic water and the admixing of polar waters from the East Greenland Current (Munda 1991). Furthermore, the temperature range between winter and summer is narrower on the west and southwest coasts than on the northern coasts as pointed out by Stefánsson (1969). There are also differences in the tidal range which is about $2.5-3.8 \mathrm{~m}$ at spring tides on the southwestern coast and about $1.5 \mathrm{~m}$ in the north (Ingólfsson 1996).

Sampling methods and data analysis

At both sites, Sandgerdi and Grimsey, a shore transect was sampled in the intertidal area. The stations per

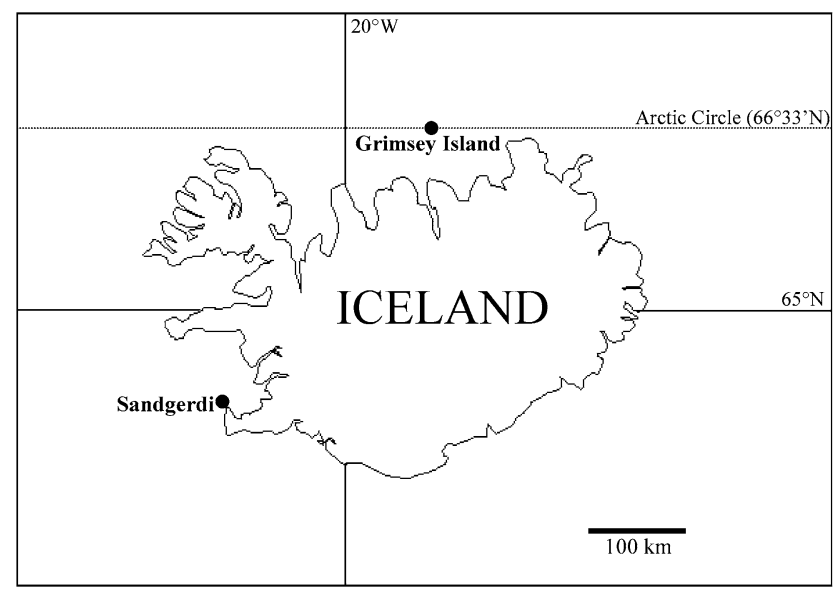

Fig. 1 Map of Iceland showing the two sampling sites, Sandgerdi and Grimsey transect were placed at fixed height intervals. A ruler, set square and rope were used to establish the different heights. The vertical interval used was $50 \mathrm{~cm}$ at Sandgerdi where the tidal range was larger $(3.5 \mathrm{~m})$, and $25 \mathrm{~cm}$ at Grimsey Island where it was smaller $(1.0 \mathrm{~m})$, following Ingólfsson (1996). The first height was the zero tidal level and the last height was the upper limit of the intertidal community. In Sandgerdi, eight levels could be considered (S1 to S8, from zero to the upper level) while only five levels were measured in Grimsey (G1 to G5). In the upper level of Sandgerdi (S8) only macrofauna was present. At each height, four replicates (quadrats $25 \times 25 \mathrm{~cm}$ ) were sampled. The surface was scraped and all specimens of algae and fauna collected. Most of the taxa were measured by biomass (algae) or abundance (macrofauna) but the patchy taxa, such as the incrustant algae Hildenbrandia rubra and Lithophyllum sp., the cirripedes Balanus crenatus and Semibalanus balanoides, the mytilid Mytilus edulis and the sponge Halichondria panicea were measured by cover. For this, the quadrats were divided into 25 units of $5 \times 5 \mathrm{~cm}$ and the presence/ absence of the species was noted for each unit (presence in the 25 subunits $=100 \%$ cover). The sponge Sycon ciliatum and the bryozoan Gemellipora eburnea were expressed in abundance since the number of individuals or colonies, respectively, could be counted. The samples were fixed in formalin $4 \%$ and brought to the laboratory for further identification and quantification after sieving (mesh size of $0.5 \mathrm{~mm}$ ). The biomass of algae was expressed in grams of wet weight per replicate $\left(625 \mathrm{~cm}^{2}\right)$, abundance of macrofauna was expressed in number of individuals per replicate, and patchy species were expressed in cover percentage.

To characterise the two sites from a physico-chemical point of view, the following variables were measured in the field: temperature, ionised ammonia $\left(\mathrm{NH}_{4}^{+}\right)$, free ammonia $\left(\mathrm{NH}_{3}\right)$, nitrites, nitrates and $\mathrm{pH}$ in water samples collected at the zero level. We used a digital thermometer for temperature, and Seachem Marine Basic $^{\odot}$ multitest for chemical measures.

Descriptive statistics provided the total number of species (S), Shannon-Wiener diversity $\left(\mathrm{H}^{\prime}\right)$ and Pielou's evenness (J) indices (Shannon and Weaver 1963; Pielou 1966). Mean values of the four replicates $\left(625 \mathrm{~cm}^{2}\right.$ each one) and standard error of mean were calculated for $\mathrm{S}$, $\mathrm{H}^{\prime}$, J, algal biomass and macrofaunal abundance. The affinities among replicate samples and sites were established through cluster analysis using the unweighted pair group method using arithmetic averages method (UPGMA) (Sneath and Sokal 1973), based on the BrayCurtis similarity index (Bray and Curtis 1957). Abundance of macrofauna and wet weight of algae were subjected to a double squared root transformation so that classification was not determined only by the most dominant species (Clarke and Green 1988). To explore the relationships among algae and the macrofaunal assemblages, a canonical correspondence analysis (CCA) was applied for each site. This is a direct gradient technique, so that the resulting stations and macrofaunal 
ranking is related directly to the values of the environmental factors (Ter Braak 1990). In this case, the algae biomass values were used as environmental factors. Multivariate analyses were carried out using the PRIMER package (Plymouth Routines In Multivariate Ecological Analysis) (Clarke and Gorley 2001) and the PC-ORD programme (McCune and Mefford 1997).

\section{Results}

\section{Abiotic data}

Temperature in July differed between the sampling sites, and was considerably lower at Grimsey $\left(8.7^{\circ} \mathrm{C}\right.$ in opposite to $13.1{ }^{\circ} \mathrm{C}$ at Sandgerdi). The other physicochemical parameters were very similar at the two sites and indicated unpolluted conditions (Table 1).

\section{Distribution of algae}

The species of algae found at Sandgerdi and Grimsey, together with the biomass values are listed in Table 2. A total of 36 species of algae were identified, 28 at Sandgerdi, and 16 at Grimsey (Fig. 2).

The lower levels (S1 and S2) of the intertidal community of Sandgerdi, were dominated by Corallina offcinalis $\left(68.44 \mathrm{~g} / 625 \mathrm{~cm}^{2}\right.$ in S1) and Laminaria spp. (1917.15 g/625 cm in S2). The medium and upper levels were characterised by high values of fucoid biomass. Fucus serratus $\left(264.95-1212.51 \mathrm{~g} / 625 \mathrm{~cm}^{2}\right)$, Fucus vesiculosus $\left(29.23-541.62 \mathrm{~g} / 625 \mathrm{~cm}^{2}\right)$ and Ascophyllum nodosum $\left(284.05-336.23 \mathrm{~g} / 625 \mathrm{~cm}^{2}\right)$ formed a dense canopy typical of the sheltered areas of the North Atlantic coast of Europe (Raffaelli and Hawkins 1996). A considerable biomass of the epiphyte Polysiphonia lanosa $\left(51.35-57.26 \mathrm{~g} / 625 \mathrm{~cm}^{2}\right)$ was found associated with Ascophyllum nodosum in S4 and S5, whereas the fucoids Fucus vesiculosus and Fucus spiralis were restricted to the upper levels (S6 and S7).

Corallina officinalis was also present in the lower level of the intertidal transect in Grimsey, but there, the belt was dominated by Alaria esculenta $\left(236.10 \mathrm{~g} / 625 \mathrm{~cm}^{2}\right)$. Palmaria palmata showed higher values of biomass at

Table 1 Physico-chemical characteristics of the two sampling localities

\begin{tabular}{lll}
\hline & Sandgerdi & Grimsey \\
\hline Sampling date & 15 July 2003 & 14 July 2003 \\
Time & $14: 00$ & $14: 45$ \\
Tide range $(\mathrm{m})$ & 3.5 & 1.0 \\
Temperature $\left({ }^{\circ} \mathrm{C}\right)$ & 13.1 & 8.7 \\
pH & 8.4 & 8.2 \\
Nitrate $(\mathrm{ppm})$ & $<0.1$ & $<0.1$ \\
Nitrite $(\mathrm{ppm})$ & $<0.05$ & $<0.05$ \\
Free ammonia (ppm) & 0.01 & 0.1 \\
Ionised ammonia (ppm) & 0.15 & 0.1 \\
\hline
\end{tabular}

Grimsey than at Sandgerdi (Table 2). Fucus distichus, and its epiphytes Elachista fucicola and Ectocarpus sp., replaced Fucus serratus and Fucus vesiculosus in the intermediate levels of the Grimsey intertidal area. At Grimsey, Ulvaria obscura was restricted to the upper limit of the intertidal transect being the exclusive species together with Enteromorpha intestinalis in G5. At Sandgerdi, however, Ulvaria obscura was distributed in the lower levels, S1 and S2, showing lower biomass than in Grimsey. The cover of Lithophyllum sp. followed the same pattern in both Sandgerdi and Grimsey, showing the highest percentages on the middle and lower shore (Table 2).

The cluster analysis based on the algal composition differentiated the samples of Sandgerdi from those of Grimsey (Fig. 3). Nevertheless, the levels S1 and S2 of Sandgerdi were grouped together with the levels G5 and G1 of Grimsey, respectively (Fig. 3A).

\section{Distribution of macrofauna}

Similar to the seaweeds, the macrofauna species richness was also higher at Sandgerdi (45 species) than at Grimsey (27 species) (Fig. 2).

The crustacean community in Sandgerdi was dominated by the gammarids Ampithoe rubricata and Jassa falcata and the isopod Idotea granulosa (Table 3). Ampithoe rubricata, Jassa falcata and Parajassa pelagica showed preferences for the lower levels while Hyale nilssoni was more abundant in the upper levels. Idotea granulosa was present throughout the whole transect whereas Idotea baltica and Idotea emarginata were found in the lowest levels, near to the sublittoral. Most of the polychaetes were also restricted to the lower levels, except for Fabricia sabella which was also present in intermediate and upper levels. Lacuna pallidula, Lacuna vincta, Littorina obtusata, Littorina saxatilis, Margarites helicinus, Nucella lapillus and Mytilus edulis were the dominant mollusc species at Sandgerdi. Lacuna spp. and Margarites helicinus were more abundant in the lower part of the transect, Nucella lapillus and Littorina obtusata preferred the intermediate zone, and Littorina saxatilis was restricted to the upper levels. Helcion pellucidum was found associated with Laminaria digitata in the level S2. The highest densities of colonies of Dynamena pumilla were found in the level S4, mainly associated with the alga Ascophyllum nodosum.

The dominant crustacean species in Grimsey were Hyale nilssoni and Idotea granulosa. Hyale nilssoni was present in all the levels sampled (G1-G5) and it was more abundant than in Sandgerdi, where it was restricted to the upper levels. The preference of Hyale nilssoni for the upper levels was already indicated by Ingólfsson (1977). Gammarus stoerensis, absent from Sandgerdi, was found in the lower and intermediate levels of Grimsey Island. This gammaridean amphipod usually inhabits semi-exposed shores (Ingólfsson 1977) such as Grimsey Island. The isopod Jaera cf prehirsuta 
Table 2 List of algal species and values of wet weight $\left(\mathrm{g} / 625 \mathrm{~cm}^{2}\right)$ in the two sampling sites

\begin{tabular}{|c|c|c|c|c|c|c|c|c|c|c|c|c|}
\hline & \multicolumn{7}{|c|}{ Sandgerdi } & \multicolumn{5}{|c|}{ Grimsey } \\
\hline & S1 & $\mathrm{S} 2$ & $\mathrm{~S} 3$ & $\mathrm{~S} 4$ & S5 & S6 & $\mathrm{S} 7$ & G1 & G2 & G3 & G4 & G5 \\
\hline \multicolumn{13}{|l|}{ Chlorophyta } \\
\hline Chaetomorpha sp. & - & 0.22 & - & - & - & - & - & - & - & - & - & - \\
\hline Cladophora rupestris (Linnaeus) Kützing & - & - & 0.54 & 0.77 & - & - & - & - & - & - & - & - \\
\hline Cladophora sp. 1 & - & - & - & - & 0.03 & 2.97 & - & - & - & - & - & - \\
\hline Cladophora sp. 2 & - & - & - & - & - & - & - & 0.01 & - & - & - & - \\
\hline Enteromorpha compressa (Linnaeus) Ness & - & - & - & - & - & 1.89 & - & - & - & - & - & - \\
\hline Enteromorpha intestinalis (Linnaeus) Ness & - & - & - & - & - & - & - & - & - & - & - & 1.01 \\
\hline Enteromorpha sp. & - & - & - & 0.01 & - & - & - & - & - & - & - & - \\
\hline Spongomorpha aeruginosa (Linnaeus) Van den Hoek & - & - & - & - & 0.01 & - & - & - & - & - & - & - \\
\hline Ulva rigida $\mathrm{C}$. Agardh & - & 1.62 & - & - & - & - & - & - & - & - & - & - \\
\hline Ulvaria obscura (Kützing) Gayral & 5.87 & 5.12 & - & - & - & - & - & - & - & - & 18.81 & 42.95 \\
\hline \multicolumn{13}{|l|}{ Phaeophyta } \\
\hline Alaria esculenta (Linnaeus) Greville & - & 236.10 & - & - & - & - & - & 314.59 & - & - & - & - \\
\hline Ascophyllum nodosum (Linnaeus) Le Jolis & - & - & - & 284.05 & 336.23 & - & - & - & - & - & - & - \\
\hline Ectocarpus sp. & - & - & - & - & - & - & - & - & - & 0.48 & 6.72 & - \\
\hline Elachista fucicola (Velley) Areschoug & - & - & - & - & - & - & - & - & - & 1.28 & 0.89 & - \\
\hline Fucus distichus Linnaeus & - & - & - & - & - & - & - & - & 6.58 & 76.70 & 323.52 & - \\
\hline Fucus serratus Linnaeus & - & 0.96 & 622.28 & 1212.51 & 401.88 & 264.95 & $5-$ & - & - & - & - & - \\
\hline Fucus spiralis Linnaeus & - & - & - & - & - & - & 44.39 & - & - & - & - & - \\
\hline Fucus vesiculosus Linnaeus & - & - & - & - & - & 541.62 & 29.23 & $3-$ & - & - & - & - \\
\hline Laminaria digitata (Hudson) J.V. Lamouroux & 0.53 & 1786.01 & - & - & - & - & - & - & - & - & - & - \\
\hline Laminaria saccharina (Linnaeus) Lamouroux & - & 131.14 & - & - & - & - & - & - & - & - & - & - \\
\hline \multicolumn{13}{|l|}{ Rhodophyta } \\
\hline Callithamnion sp. & - & - & - & - & - & - & - & - & 6.25 & 0.13 & - & - \\
\hline Ceramium rubrum C. Agardh & 0.77 & 0.02 & - & - & - & - & - & - & - & - & - & - \\
\hline Ceramium sp. & - & - & - & - & - & - & - & - & 2.88 & - & - & - \\
\hline Chondrus crispus Stackhouse & 9.43 & 4.29 & - & - & - & - & - & - & - & - & - & - \\
\hline Corallina officinalis Linnaeus & 68.44 & 2.32 & - & - & - & - & - & 8.31 & 0.32 & - & - & - \\
\hline Cystoclonium purpureum (Hutson) Batters & - & 0.07 & - & - & - & - & - & - & - & - & - & - \\
\hline Delesseria sanguinea (Hutson) J.V. Lamouroux & - & - & 2.99 & - & - & - & - & - & - & - & - & - \\
\hline Gastroclonium sp. & 0.09 & - & - & - & - & - & - & - & 8.87 & 5.31 & - & - \\
\hline Hildenbrandia rubra (Sommerfelt) Meneghini ${ }^{\mathrm{a}}$ & - & - & 11.00 & 16.00 & - & 2.00 & - & 2.00 & - & - & - & - \\
\hline Lithophyllum sp. ${ }^{\mathrm{a}}$ & 10.00 & 14.00 & 28.00 & 48.00 & 1.00 & 1.00 & - & & 68.00 & 33.00 & - & - \\
\hline Mastocarpus stellatus (Stackhouse) Guiry & - & 4.06 & 0.64 & - & - & - & - & - & - & - & - & - \\
\hline Palmaria palmata (Linnaeus) Kuntze & - & 1.73 & 9.45 & - & - & - & - & - & 1.93 & 28.62 & 2.70 & - \\
\hline Polysiphonia lanosa (Linnaeus) Tandy & - & - & - & 51.35 & 57.26 & - & - & - & - & - & - & - \\
\hline Porphyra umbilicalis (Linnaeus) Kützing & - & - & 0.08 & - & 1.50 & - & - & - & - & - & - & - \\
\hline Rhodomela lycopodioides (Linnaeus) C. Agardh & - & - & - & - & - & - & - & - & 0.32 & - & - & - \\
\hline Rhodophyta unidentified & 0.01 & - & - & - & - & - & - & - & 0.32 & - & - & - \\
\hline
\end{tabular}

Values are means of four replicates each

${ }^{a}$ Cover percentage $(\%)$ instead of biomass values

was present in the lower levels at Grimsey, whereas at Sandgerdi this species was distributed in the upper zone. The mollusc and polychaete communities were less diverse at Grimsey than at Sandgerdi, but the distribution patterns of the dominant species were similar in both sites. The ratio oligochaeta/nematoda was higher at Grimsey.

The discrimination of fauna between the two sites, Sandgerdi and Grimsey, in the dendrogram (Fig. 4) is less evident than for the algae (Fig. 3). The four replicates of each level appeared grouped, but the levels of both sites were not clearly separated.

\section{Relationships between algae and macrofauna}

The general patterns of species richness for both algae and macrofauna were similar at Sandgerdi and Grimsey (Fig. 5). There was an expected decrease from the lower to the upper levels of the intertidal zone. However, whereas the maximum number of species of macrofauna was reached in the zero level (S1 and G1), the maximum species richness of algae was found in the second level (S2 and G2).

The diversity $\left(\mathrm{H}^{\prime}\right)$ and evenness $(\mathrm{J})$ patterns were different from those obtained for the species richness, and also differed between Sandgerdi and Grimsey (Figs. 6 and 7). In the lower area of the intertidal zone, the $\mathrm{H}^{\prime}$ and $\mathbf{J}$ patterns for the algae were the opposite of those for the macrofauna. At Grimsey, both $\mathrm{H}^{\prime}$ and $\mathbf{J}$ for algae increased from G1 to G2 while the values for the macrofauna decreased. At Sandgerdi, however, $\mathrm{H}^{\prime}$ and J for algae decreased from S1 to S2 while the values for macrofauna increased. At Sandgerdi, for low shore algae, the increase in species richness was associated with an increase in biomass (Figs. 5 and 8). On the other hand, for the macrofauna, the decrease in species richness was associated with a decrease in macrofaunal 


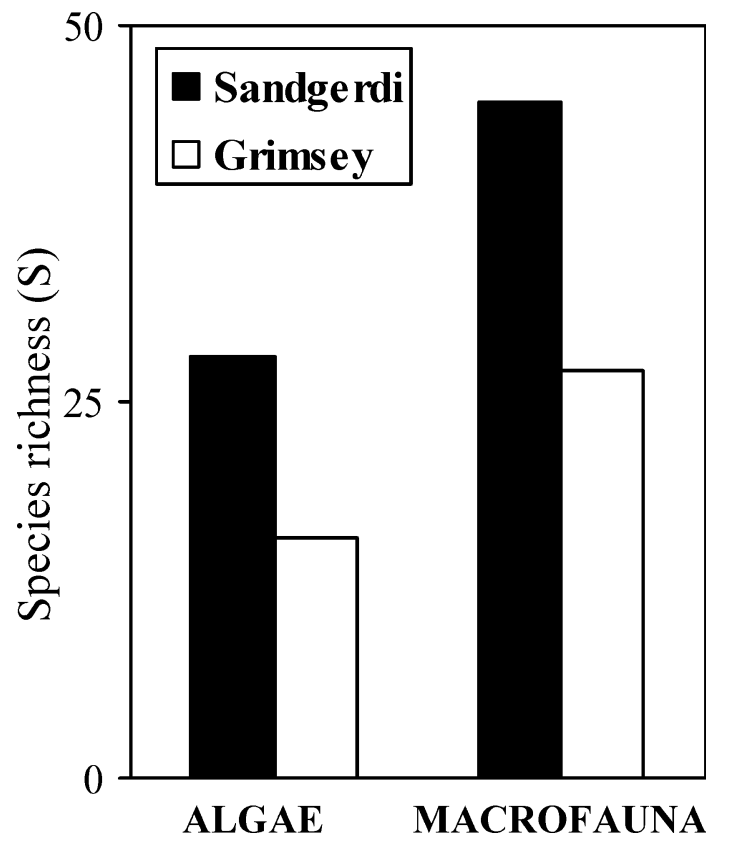

Fig. 2 Algae and macrofauna species richness in the intertidal zones of Sandgerdi and Grimsey, respectively

abundances. In the upper levels, the obtained patterns for algae and macrofauna were similar: a decrease in $\mathrm{S}$, $\mathrm{H}^{\prime}$ and $\mathbf{J}$ was associated with a decrease in algal biomass and macrofaunal densities. At Grimsey, for the algae, the increase in the $\mathrm{S}, \mathrm{H}^{\prime}$ and $\mathrm{J}$ from level $\mathrm{G} 1$ to $\mathrm{G} 2$ was associated with a decrease in the biomass, and the opposite pattern was found for the abundance of macrofauna (Fig. 8). In the upper levels, the patterns were similar to those obtained for Sandgerdi, except for the algal biomass of level G4, which was higher than expected because of the massive belt of Fucus distichus (Table 2).

The CCA showed that the alga Corallina officinalis, dominant in the lower levels of both sites, was determining for the presence of polychaetes and the amphipod gammaridean Jassa falcata (Figs. 9 and 10). According to the CCA, Corallina officinalis turned out to have the highest effect on macrofaunal assemblages, showing the highest correlation values with axis 1 in both locations (Table. 4 and 5). The distribution of Chondrus crispus in the levels S1 and S2 of Sandgerdi probably influenced, together with Corallina officinalis, the distribution of the gammarids Amphitoe rubricata and Parajassa pelagica (Fig. 9). The fucoid Fucus serratus, dominant in the intermediate levels of Sandgerdi and significantly correlated with axis 2 of the CCA analysis (Table 4), was populated by the grazer community (mainly by the species Lacuna pallidula, Littorina obtusata, and Hyale nilssoni) (Fig. 9). For Grimsey, the axis 2 of the analysis was correlated mainly with Ulvaria obscura, associated with the highest densities of Hyale nilssoni and Littorina saxatilis (Table 5). The rhodophyte Callithamnion sp was also correlated with axis 2 supporting considerable oligochaete abundances (Fig. 10).

\section{Additional data}

Additional observations were made at Kulusuk, Greenland, in July 2003 . Water temperature was $2-3^{\circ} \mathrm{C}$ and the intertidal communities were composed by Fucus distichus $\left(150-200 \mathrm{~g} / 625 \mathrm{~cm}^{2}\right)$ and Fucus vesiculosus in the upper zone $\left(75-100 \mathrm{~g} / 625 \mathrm{~cm}^{2}\right)$ while other algae were missing. The macrofaunal community was also very reduced, composed by the gammaridean Gammarus finmarchicus $\left(5-10\right.$ ind $\left./ 625 \mathrm{~cm}^{2}\right)$ in the lower zone and Littorina saxatilis $\left(25-30\right.$ ind $\left./ 625 \mathrm{~cm}^{2}\right)$ in the upper areas. Semibalanus balanoides was also present (cover $10 \%$ ) but did not form a clear belt.

\section{Discussion}

The present study represents a first approach to the relationships between algae and macrofauna in two intertidal ecosystems of Iceland characterised by different seawater temperature. The results show differences in species composition, diversity and evenness between the two sites; however, it is difficult to establish causes and effects. It is necessary to consider that the tidal range is higher at Sandgerdi and, consequently, there is much more intertidal substrate for colonisation in this site. Grimsey, in contrast, is characterised by a more exposed shore than Sandgerdi.

The cluster analyses of replicates for algae showed consistence within each site, except for levels S1 and G5, which are clustered together due to the presence of $\mathrm{Ul}$ varia obscura. This species reached higher levels at Grimsey than at Sandgerdi which may be due to the stronger wave exposure at Grimsey. On the other hand, S2 and G1 appeared grouped since level 1 is virtually subtidal at Sandgerdi due to the high tidal range, and the level 2 corresponds to the laminarian belt (level 1) at Grimsey. The discrimination between sites was not clear, however, when macrofaunal abundances were used; differences in physical conditions probably affect the algal community more than the macrofauna which is mostly motile. When cluster analyses are applied to group species, several algae groups can be distinguished. Corallina officinalis and Chondrus crispus appear together forming a typical lower level of red seaweeds. Similarly, Laminaria digitata and Alaria esculenta form a typical laminarian level. Elachista fucicola and $\phi E c t o-$ carpus sp. also appear together since both are epiphytes of Fucus, like Polysiphonia lanosa and its host Ascophyllum nodosum. Finally Enteromorpha compressa and Cladophora sp 2. form an association in the cluster, since both species were found under the drier conditions of the upper levels. Some interesting groups can be also observed for the macrofauna, such as the grazer assemblage (Littorina obtusata, Lacuna pallidula, Margarites 
Fig. 3 Dendrograms based on algae biomass; A classification of stations according to algae composition; B classification of algae according to their biomass in the different stations. Bray Curtis similarity index and UPGMA method have been used. Data were transformed with the fourth root. The letters $a, b, c$, and $d$ indicate replicate samples
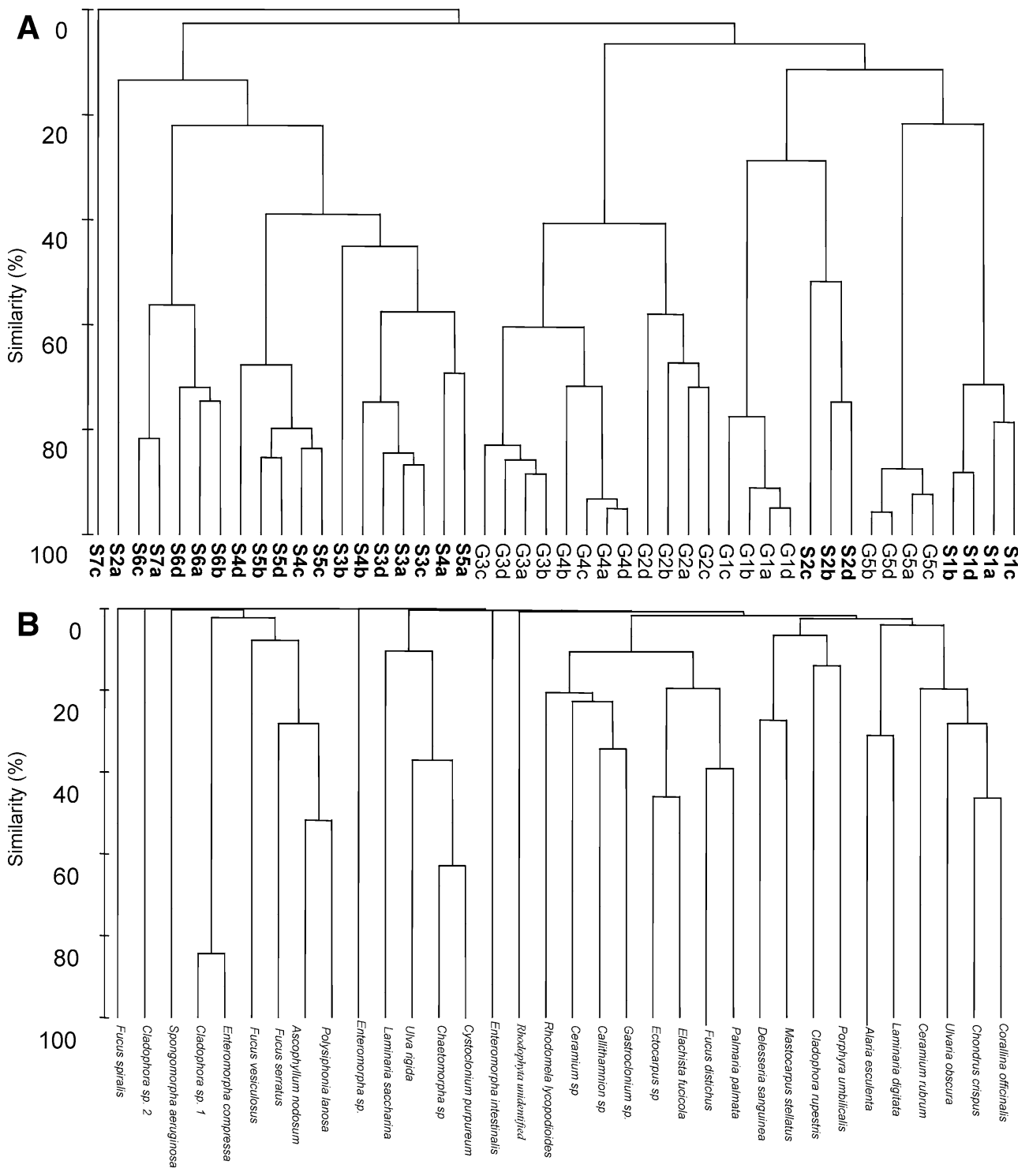

helicinus and Lacuna vincta), the polychaete-nemertea group (Eulalia viridis, Cirratulus cirratus, Nemertea) associated with Corallina officinalis, and the isopod Idotea granulosa together with the oligochaeta, which were very abundant on Polysiphonia. The canopy of Polysiphonia probably contributes to an adequate refuge or reproductive habitat for Idotea, which feeds mainly on fucoids (Haahtela 1984; Leifsson 1998).

Within the upper sublittoral zone, Laminaria digitata and L. saccharina appear in exposed and protected sites, respectively, on south and southwestern coasts of Iceland, while Alaria esculenta dominates on exposed rocky sites (Munda 1991). This is the pattern found also in the present study. Laminaria saccharina was present at Sandgerdi, together with $L$. digitata and $A$. esculenta . At Grimsey only A. esculenta was present, and this alga showed a higher biomass than at Sandgerdi, indicating more exposed conditions according to Ballantine (1961). This is the dominant association in the upper sublittoral at Grimsey (Munda 1977c). According to Munda (1977a, b) lower eulittoral belts of Mastocarpus stellatus and Corallina offcinalis are a characteristic feature of south, southwestern and northwestern coasts of Iceland. In the present study we found high biomass of Mastocarpus stellatus, Chondrus crispus and Corallina officinalis at Sandgerdi. Low biomass was observed for Corallina officinalis in Grimsey where Chondrus crispus and Mastocarpus stellatus were missing. Corallina officinalis appeared in the present study in a slightly lower level than Mastocarpus stellatus as was reported by Munda (1977a) for Icelandic coasts. On the other hand, the Palmaria palmata association is dominant in the low-eulittoral, and is one of the characteristic features of the Grimsey vegetation (Munda 1977c). In the present study we measured a high biomass of Palmaria palmata at Grimsey. A complete fucoid zonation, ranging from Pelvetia canaliculata over $\mathrm{Fu}$ cus spiralis, $F$. vesiculosus, Ascophyllum nodosum to Fucus serratus is characteristic of the relatively warm 
Table 3 Density values of macrofaunal taxa (ind $/ 625 \mathrm{~cm}^{2}$ ) for the two sampling sites

\section{Sandgerdi}

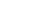

Grimsey

G1 G2 G3 G4 G5

Crustacea

Cirripedia

Balanus crenatus Bruguière, 1789

Semibalanus balanoides (Linnaeus, 1758) ${ }^{\mathrm{a}}$

Decapoda

Carcinus maenas (Linnaeus, 1758)

Gammaridea

Ampithoe rubricata(Montagu, 1808)

Corophium bonnelli(Milne-Edwards, 1830)

Gammarus obtusatus Dahl, 1938

Gammarus stoerensis (Reid, 1938)

Hyale nilssoni(Milne-Edwards, 1830)

Jassa falcata (Montagu, 1808)

Parajassa pelagica (Leach, 1814)

Isopoda

Idotea baltica (Pallas, 1772)

Idotea emarginata (Fabricius, 1793)

Idotea granulosa Rathke, 1843

Jaera cf prehirsuta Forsman, 1949

Mollusca

Gasteropoda

Buccinum undatum Linnaeus, 1758

Helcion pellucidum Linnaeus, 1758

Lacuna pallidula (Da Costa, 1778)

Lacuna vincta (Montagu, 1803)

Littorina obtusata (Linnaeus, 1758)

Littorina saxatilis (Olivi, 1792)

Margarites groenlandicus (Gmelin, 1791)

Margarites helicinus (Phipps, 1774)

Nucella lapillus (Linnaeus, 1758)

Skeneopsis planorbis (Fabricius O., 1780)

Bivalvia

Cyamium minutum

Mytilus edulis Linnaeus, $1758^{\mathrm{a}}$

Polychaeta

Arenicolidae sp

Cirratulus cirratus (O.F. Müller, 1776)

Etenoe longa (Fabricius, 1780)

Eulalia viridis (Linnaeus, 1767)

Fabricia sabella (Ehrenberg, 1836)

Lepidonotus squamatus (Linnaeus, 1758)

Nephtyidae sp.

Scoloplos armiger (O.F.Müller, 1776)

Spionidae sp.

Hydrozoa

Dynamena pumilla (Linnaeus, 1758)

Porifera

Halichondria panicea (Pallas, 1766) ${ }^{\mathrm{a}}$

Sycon ciliatum (Fabricius, 1780)

Briozoa

Gemellipora eburnea (Smith, 1873)

Scrupocellaria arctica (Busk, 1855)

Anthozoa

Urticina felina Linnaeus, 1761

Echinodermata

Leptasterias muelleri (M.Sars, 1846)

Picnogonida

Nymphon gracile Leach, 1814

Insecta

Nematoda

Oligochaeta

Sipuncula

Nemertea

\begin{tabular}{|c|c|c|c|c|c|c|c|c|c|c|c|c|}
\hline- & - & - & - & - & - & - & - & 5.0 & 3.0 & - & - & - \\
\hline- & - & - & - & 3.0 & - & 29.0 & - & - & - & 26.0 & 42.0 & - \\
\hline 0.3 & 0.3 & - & - & - & - & - & - & - & - & - & - & - \\
\hline 667.0 & 56.3 & 2.0 & 4.5 & - & - & - & - & 2.0 & - & - & - & - \\
\hline 3.3 & - & - & - & - & - & - & - & - & - & - & - & - \\
\hline- & - & - & - & - & 1.0 & - & - & - & - & - & - & - \\
\hline- & - & - & - & - & - & - & - & 0.3 & 5.0 & 0.3 & - & - \\
\hline- & - & - & 0.3 & 43.5 & 1.8 & 4.3 & - & 0.8 & 3.3 & 7.0 & 70.8 & 23.5 \\
\hline 621.3 & - & - & - & - & - & - & - & 5.0 & - & - & - & - \\
\hline 51.0 & 35.3 & - & 0.3 & - & 0.3 & - & - & - & - & - & - & - \\
\hline 12.3 & - & 0.5 & - & - & - & - & - & - & - & - & - & - \\
\hline 0.5 & - & - & - & - & - & - & - & - & - & - & - & - \\
\hline 79.8 & 8.5 & 12.0 & 199.8 & 380.8 & 2.3 & - & - & 1.5 & 18.8 & 5.5 & 12.5 & - \\
\hline- & - & - & - & - & - & 3.0 & - & 1.0 & 2.5 & - & - & - \\
\hline
\end{tabular}

Acarina

\begin{tabular}{|c|c|c|c|c|c|c|c|c|c|c|c|}
\hline 0.3 & - & - & - & - & - & - & - & - & - & - & - \\
\hline- & 13.0 & - & 0.3 & - & - & - & - & - & - & - & - \\
\hline- & 25.5 & 21.8 & 7.5 & - & 3.5 & 4.0 & - & - & - & - & - \\
\hline 5.8 & 24.8 & 1.0 & 2.5 & - & - & - & - & 1.0 & - & - & - \\
\hline 2.5 & 8.5 & 6.5 & 5.5 & 6.5 & 38.5 & 2.5 & - & 0.3 & 1.3 & 2.0 & 2.8 \\
\hline- & - & - & - & - & 0.5 & 43.5 & 40.9 & 0.3 & 1.3 & - & 0.8 \\
\hline- & - & - & - & - & 0.5 & - & - & - & - & - & - \\
\hline 22.0 & 22.0 & 5.3 & 1.3 & - & - & - & - & 22.3 & - & - & - \\
\hline 2.3 & 0.8 & 4.3 & 10.3 & 7.3 & 0.8 & - & - & - & - & - & - \\
\hline 1.0 & - & - & - & - & - & - & - & - & 256.5 & 24.0 & 1.8 \\
\hline
\end{tabular}

Values are means of four replicates each

${ }^{\mathrm{a}}$ Cover percentage $(\%)$ instead of biomass values 
Fig. 4 Dendrograms based on macrofauna abundances; $A$ classification of stations according to macrofaunal composition; B classification of macrofaunal species according to their abundances in the different stations. Bray Curtis similarity index and UPGMA method have been used. Data were transformed with the fourth root. The letters $a, b, c$, and $d$ indicate replicate samples
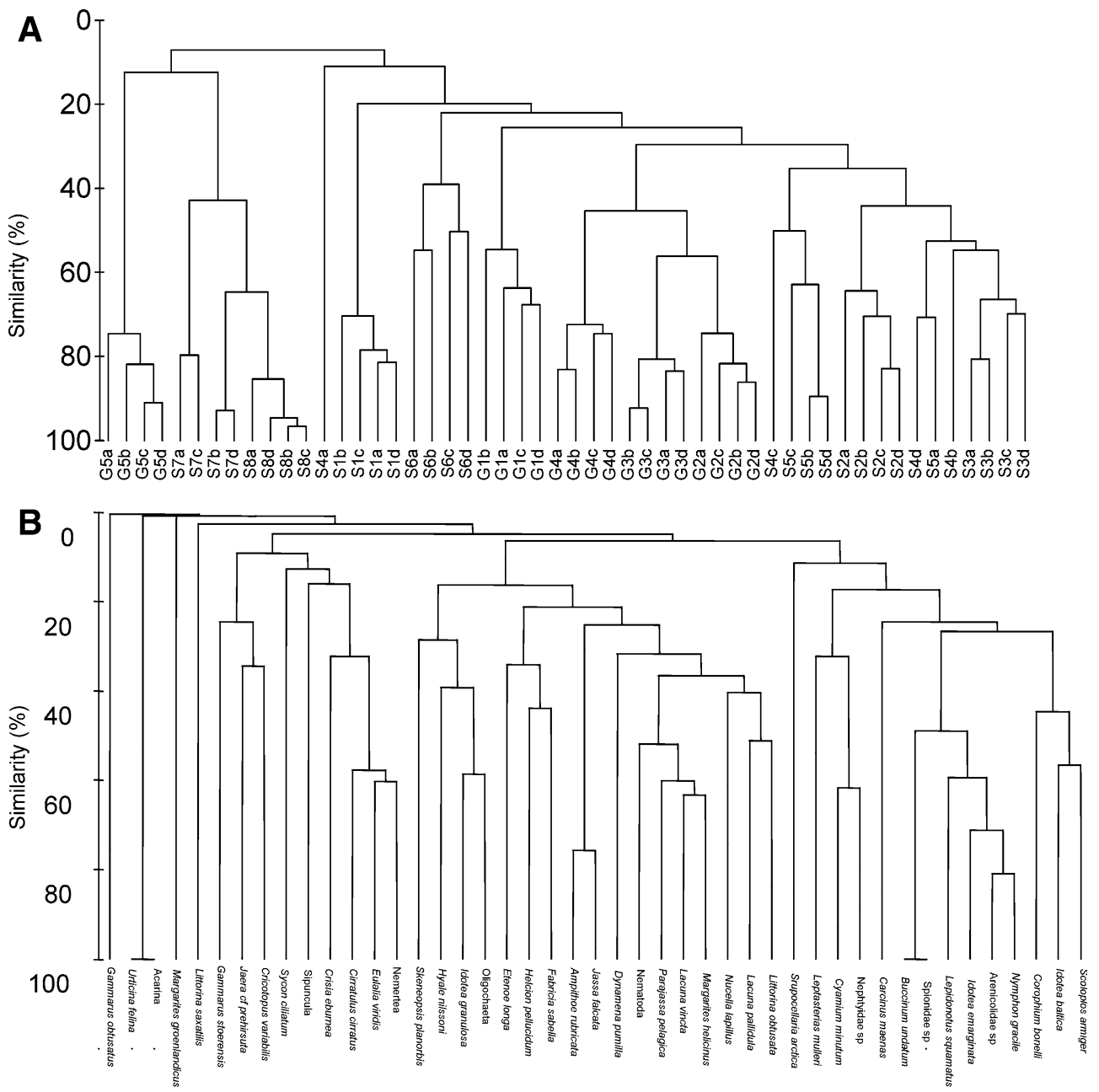

southern coast of Iceland (Munda 1972). The number of fucoid belts is reduced in northwestern and northeastern Iceland; in these colder regions Fucus distichus is the main fucoid species (Munda 1991). Our quantitative results are in agreement with the qualitative observations of Munda. There are great differences between Sandgerdi and Grimsey. At Sandgerdi, we measured a high biomass of different fucoids $(5.36 \mathrm{~kg} /$ $\mathrm{m}^{2}$ for $A$. nodosum; and $6 \mathrm{~kg} / \mathrm{m}^{2}$ measured by Munda 1991 for South Iceland) while at Grimsey we only registered the presence of Fucus distichus. The fucoids occur from the low to the upper eulittoral zone. The presence of Porphyra umbilicalis forming an inconspicuous belt with other species in the upper eulittoral, is a feature of south and southwestern coasts of Iceland (Munda 1991); we found Porphyra umbilicalis at Sandgerdi in the upper eulittoral (S5: $2 \mathrm{~m}$ above zero tidal height) but not at Grimsey. Furthermore, belts of small mussel shells are more frequent at Sandgerdi than at Grimsey as pointed out by Munda (1991) for south and southwestern coasts.

Only a few species tolerate long emersion periods with strong desiccation, and the community becomes progressively simplified in the upper levels. This probably is the reason why diversity and evenness values at both Sandgerdi and Grimsey decreased towards the upper levels. In Sandgerdi, level S2, dominated by laminarians, shows a high biomass but low values of $\mathrm{H}^{\prime}$ and $\mathrm{J}$. Laminarians dominate the substrate, producing shadow and sweeping the substrate, thus allowing only a few algal species to grow (Corallina officinalis and encrusting pink algae among them).

Trophic and spatial relationships between algae and macrofauna

Algae provide food and refuge for animals to live and breed (Nicotri 1980; Albrecht and Reise 1994; Schreider et al. 2003). In the present study, the macrofaunal abundance did not seem to be directly influenced by the algal biomass. At Sandgerdi, there was a low algal biomass in $\mathrm{S} 1$ but a high macrofaunal abundance, and in S2 the pattern was the opposite. At Grimsey the situation was similar but it was in G1 where the algal biomass was high and macrofaunal abundance low, and the reverse was found in G2. Therefore, the algal 
SPECIES RICHNESS (S)
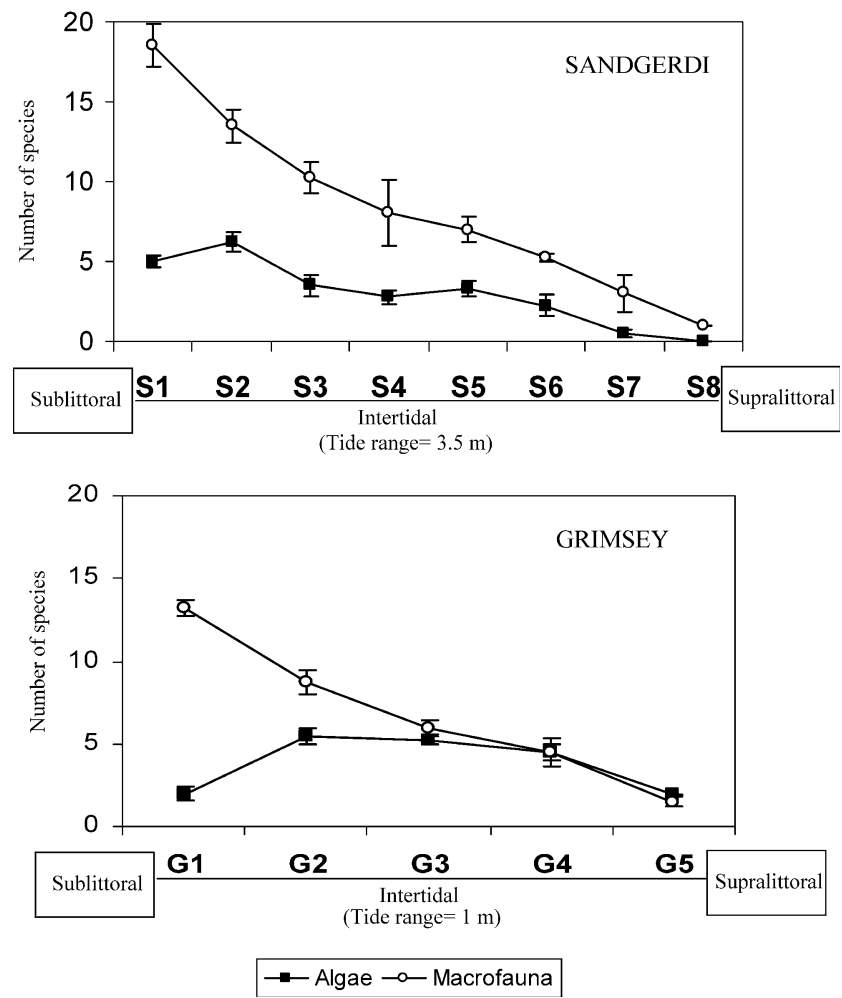

Fig. 5 Species richness of algae and macrofauna along intertidal transects at Sandgerdi and Grimsey. Samples were taken every $50 \mathrm{~cm}$ at Sandgerdi, and every $25 \mathrm{~cm}$ at Grimsey. Values are means of four replicates each and the bars indicate standard errors of the means

structure is probably the critical factor in controlling the macrofaunal abundance. For example, fucoid algae have been found associated with higher values of macrofaunal diversity (Albrecht and Reise 1994). The biomass of Corallina officinalis in S1 is low; however, due to its habitus, this alga provides an excellent refuge for polychaetes and crustaceans, as shown by the CCA analyses; the relationship is clearly based on the factor refuge since the calcified structure of Corallina officinalis prevents grazing activities (Littler and Kauker 1984). A similar pattern is shown by Chondrus crispus which offers adequate habitat for several gammarid species. On the other hand, in S2, the high algal biomass provided by laminarians is not associated with high macrofaunal abundance because only the haptera are adequate as refuge. In G1, the situation is analogue to S2; Alaria esculenta dominates with high biomass but only its haptera are used for refuge. In G2 the presence of the rhodophyts Callithamnion sp. and Palmaria palmata increase the opportunities of refuge, and different taxa appeared associated, as shown by the CCA analysis. In S4 and S5, high algal biomass was related to high macrofaunal abundance. In this case the high biomass of Ascophyllum nodosum determines the abundance of its epiphyte Polysiphonia lanosa (51.35 g in S4 and $57.26 \mathrm{~g}$ in S5). This epiphytic species has a

\section{DIVERSITY (H')}
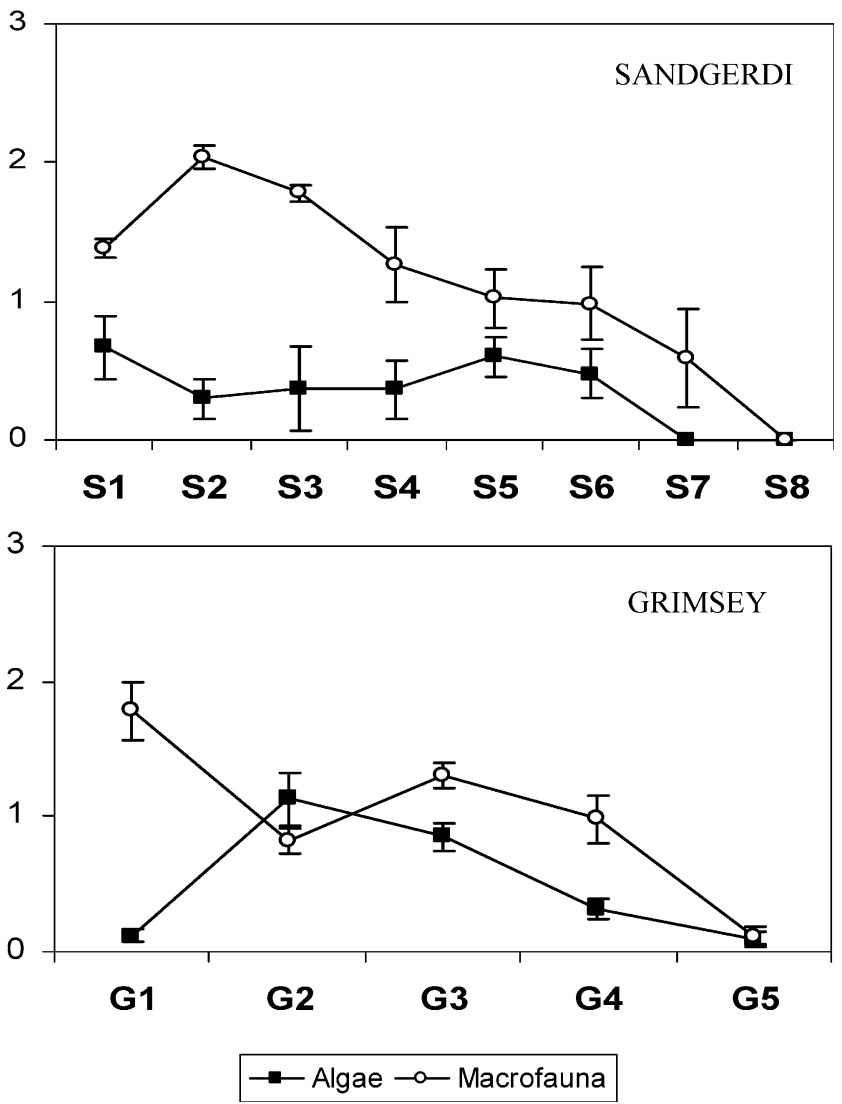

Fig. 6 Diversity (Shannon-Wiener index) of algae and macrofauna along intertidal transects at Sandgerdi and Grimsey. Samples were taken every $50 \mathrm{~cm}$ at Sandgerdi, and every $25 \mathrm{~cm}$ at Grimsey. Values are means of four replicates each and the bars indicate standard errors of the means

branched structure which provides an excellent habitat for many species, especially for Idotea granulosa (194.8 individuals in S4 and 380.8 in S5). This isopod feeds mainly on Fucus spp. which grows close to Ascophyllum nodosum while the Polysiphonia canopy may provide refuge instead of food.

The CCA analysis shows that several grazer taxa were associated with Fucus serratus (mainly molluscs and gammarids). In this context, the grazers Littorina obtusata, Lacuna pallidula, and the gammarid Hyale nilssoni, very common at Sandgerdi, may feed on small propagules and spores of Fucus spp. and may use the Fucus canopy as refuge as well. Strong relationships have been shown between Littorina spp. and algae (Williams 1990; Albrecht and Reise 1994). At Grimsey, Ulvaria obscura was correlated with the abundance of the grazers Hyale nilssoni and Littorina saxatilis, as shown by the CCA. The grazers Hyale nilssoni and Littorina saxatilis probably use Ulvaria obscura as a trophic resource due to the alga's fragile and foliose habitus which facilitates its consumption, while the alga probably does not provide adequate refuge. 


\section{EVENNESS (J)}
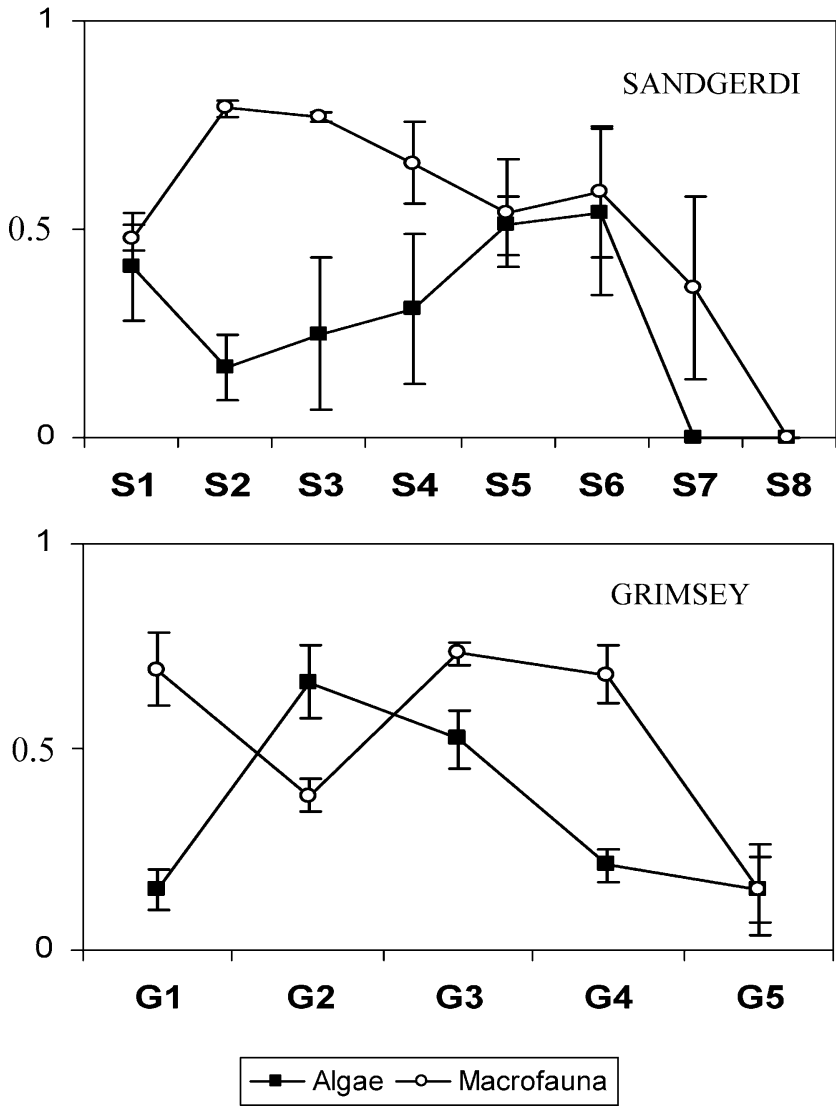

Fig. 7 Eveness (Pielou index) of algae and macrofauna along intertidal transects at Sandgerdi and Grimsey. Samples were taken every $50 \mathrm{~cm}$ at Sandgerdi, and every $25 \mathrm{~cm}$ at Grimsey. Values are means of four replicates each and the bars indicate standard errors of the means

\section{Temperature as structuring factor}

Differences between the main vegetation types around Iceland may be primarily due to the effects of temperature (Munda 1991). The general pattern of zonation described in this study agrees with that described by Munda for Iceland. The communities at Sandgerdi and Grimsey can thus be considered as representatives of different hydrographic regimes. The factors controlling community structure such as predation, competition, local hydrographic conditions are complex. Exposure is an important factor determining community structure. Grimsey is characterised by high exposure and severe climatic conditions, with a profound local cooling effect due to the drift ice (Munda 1977c). According to the classification of Ingólfsson (1977) of fucoid shores of Iceland, Sandgerdi is considered a sheltered shore (type 1, Ascophyllum shore), and Grimsey is considered an exposed shore (type 3, Fucus distichus shore). This classification, based on the species composition and called "fucoid rank", is highly correlated with the exposure index (Hansen and Ingólfsson 1993). Generally, exposed areas show higher values of
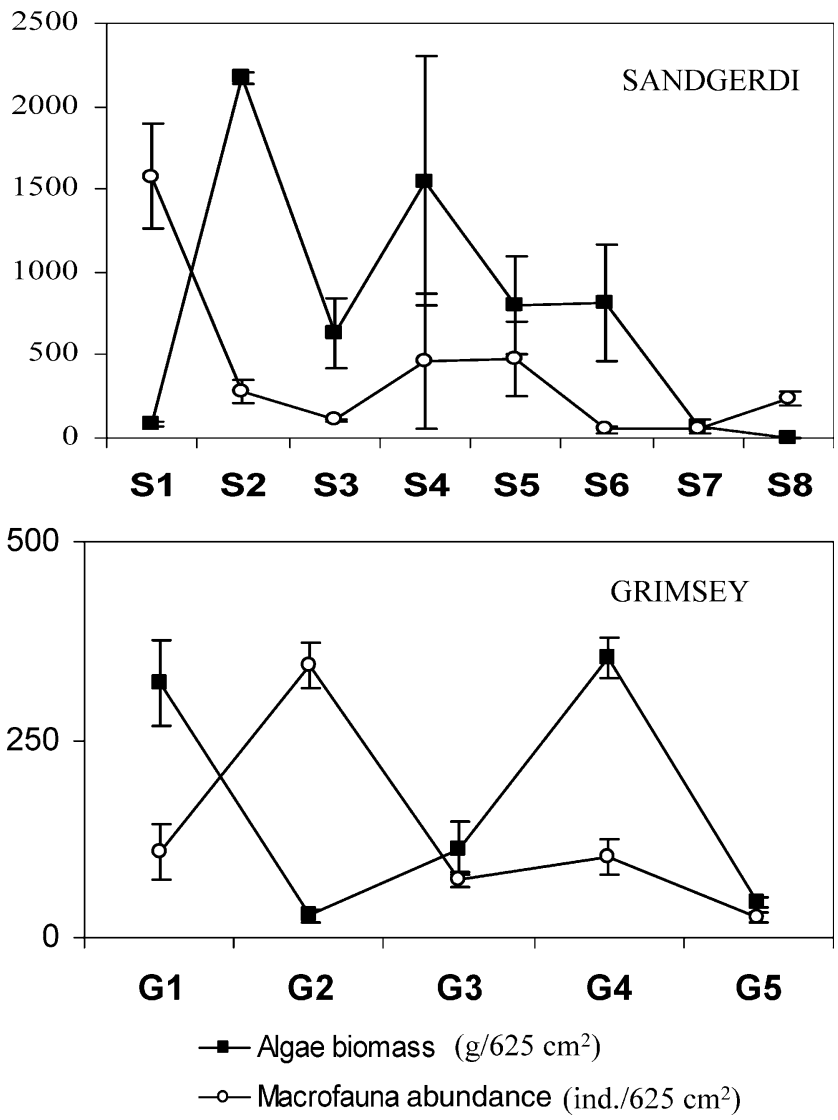

Fig. 8 Algae biomass $\left(\mathrm{g} / 625 \mathrm{~cm}^{2}\right)$ and macrofauna abundance (ind $/ 625 \mathrm{~cm}^{2}$ ) along intertidal transects at Sandgerdi and Grimsey. Samples were taken every $50 \mathrm{~cm}$ at Sandgerdi, and every $25 \mathrm{~cm}$ at Grimsey. Values are means of four replicates each and the bars indicate standard errors of the means

diversity and evenness than sheltered shores. The effect of wave exposure in structuring nearshore communities has been well documented by Lewis (1964), Seapy and Littler (1978) and Engledow and Bolton (1994). Results from these studies indicate that, at least for algal communities, diversity increases with wave exposure. However, in the present study, similar values of diversity and evenness were measured for both sites, and the values were even higher in the more sheltered area of Sandgerdi. According to Munda (1977c) there is a slight floristic impoverishment at the island of Grimsey. This impoverishment may be related to the severe climatic conditions as commented by Munda. In this case, temperature might play an important role as structuring factor. Southern Iceland is characterised by a high floristic diversity and high biomass of most algal populations, and the flora is impoverished at the northwestern coasts (Munda 1991). The colder environment of Grimsey may determine the absence or scarce presence of some species, which are present or abundant at Sandgerdi. According to Munda (1975, 1976), there are conspicuous hydrographic changes in the northwestern part of Iceland and a sharp floristic discontinuity occurs around Hornbjarg in the extreme 
northwest. Several species gradually disappear along the north coasts of Iceland, and there is a depletion of undergrowth species beneath fucoid algae occurs (Munda 1991). This fact might explain the differences in diversity between Sandgerdi and Grimsey; at Grimsey, the low biomass and species richness of fucoids could be responsible for a loss of undergrowth species such as Cladophora rupestris. This situation also occurs for the gammarids Amphitoe rubricata, Jassa falcata or Parajassa pelagica, the isopods Idotea spp. and the mollusc Lacuna palidula, Littorina obtusata or Margarites helicinus. Ingólfsson (1977) concluded that temperature is an important factor controlling the distribution of Icelandic amphipods. The higher ratio oligochaeta/nematoda at Grimsey could be related to the high resistance of oligochaetes to cold waters which was demonstrated experimentally by Davenport and Macalister (1996). The lower air temperature at Grimsey could also contribute to reduce the community in the upper levels. A simplification of the community associated with a decrease in seawater and air temperature also occurs on east Greenland shores. As pointed out by Ingólfsson $(1977,1992)$ many species inhabiting surrounding warmer areas (North Norway, Iceland and Canadian Maritimes) are lacking in the considerably colder marine environment of Greenland.
Our personal observations in Greenland indicate that the intertidal assemblages were restricted to the inner part of fjords in which abrasion by icebergs is lower than on exposed shores. According to Munda (1991), fucoids are limited to protected shores and rocky fissures in Southern Greenland. The extreme cold temperatures seem to determine the low diversity of these intertidal communities of Greeenland. Additionally, the negative impact of the ice scraping on the shore could limit the diversity of these areas. Coastal ice impacts have been often suggested to explain the depauperation of the Antarctic littoral communities (Jazdzewski et al. 2001).

Acknowledgements We are very grateful to Dr. Gudmundur Vidir Helgason for arrangements, help and hospitality during our stay at the Sandgerdi Marine Centre (SMC), Iceland, and for making available the invertebrate collections from the international BIOICE project (Benthic Invertebrates of Icelandic waters). Thanks are also due to Dr. Gudmundur Gudmunson, Dr. Halldór Pálmar Halldórson and all the staff of the $S M C$ for their kindness and help. The stay at the $S M C$ was supported by the programme "Improving Human Potential: Access to Research Infrastructure" (IHP/ARI) provided by the European Community and by the Ministry of Education and Culture of Spain (grant FPU AP 35562001 to F. Espinosa). Our thanks also go to the anonymous referees which have greatly contributed to improve the manuscript with their comments.
Fig. 9 Graph representation of the macrofaunal species and algae with respect to the first two axes of the CCA carried out for the Sandgerdi data on macrofaunal abundance and algal biomass; see also Table 4

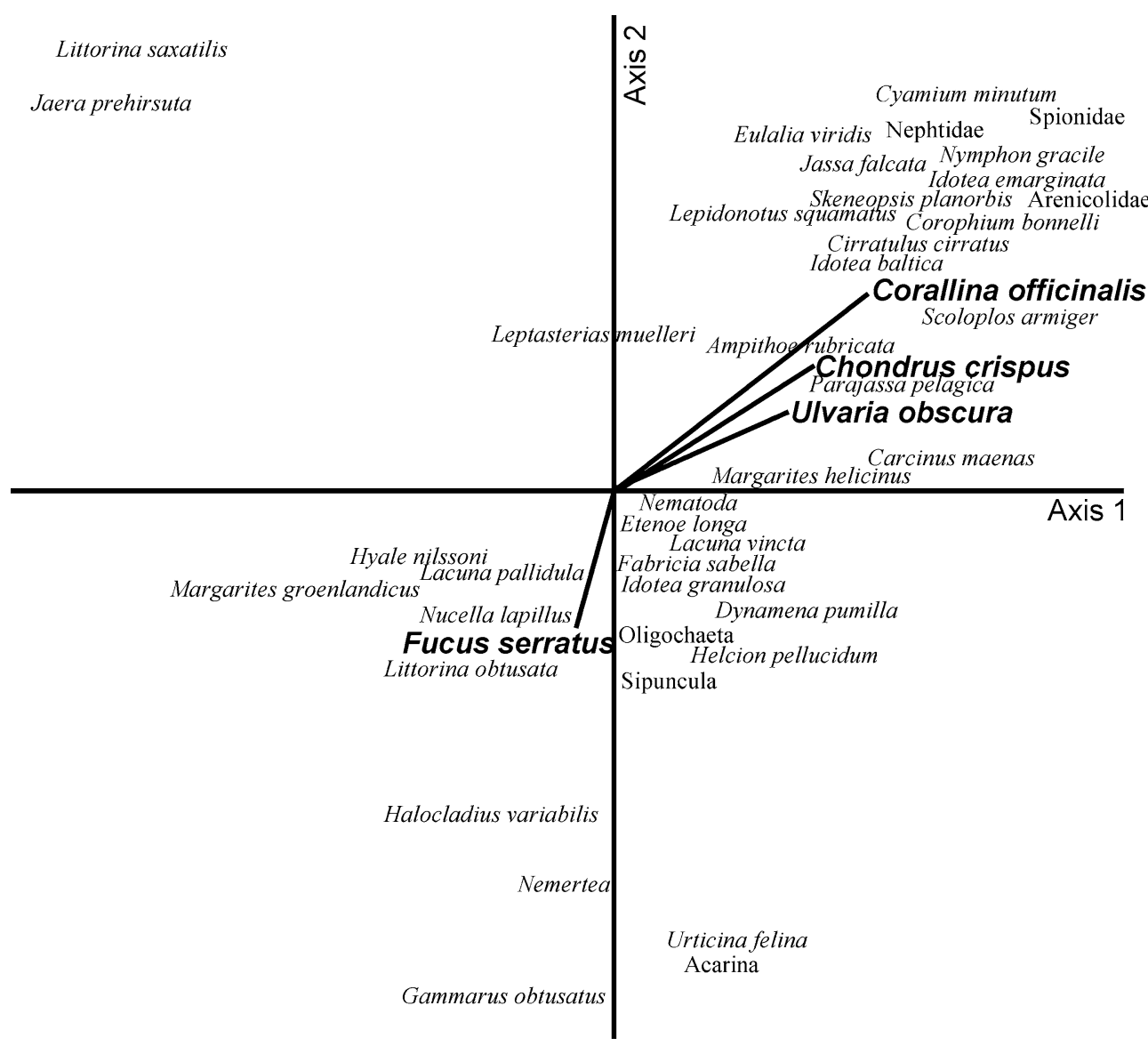




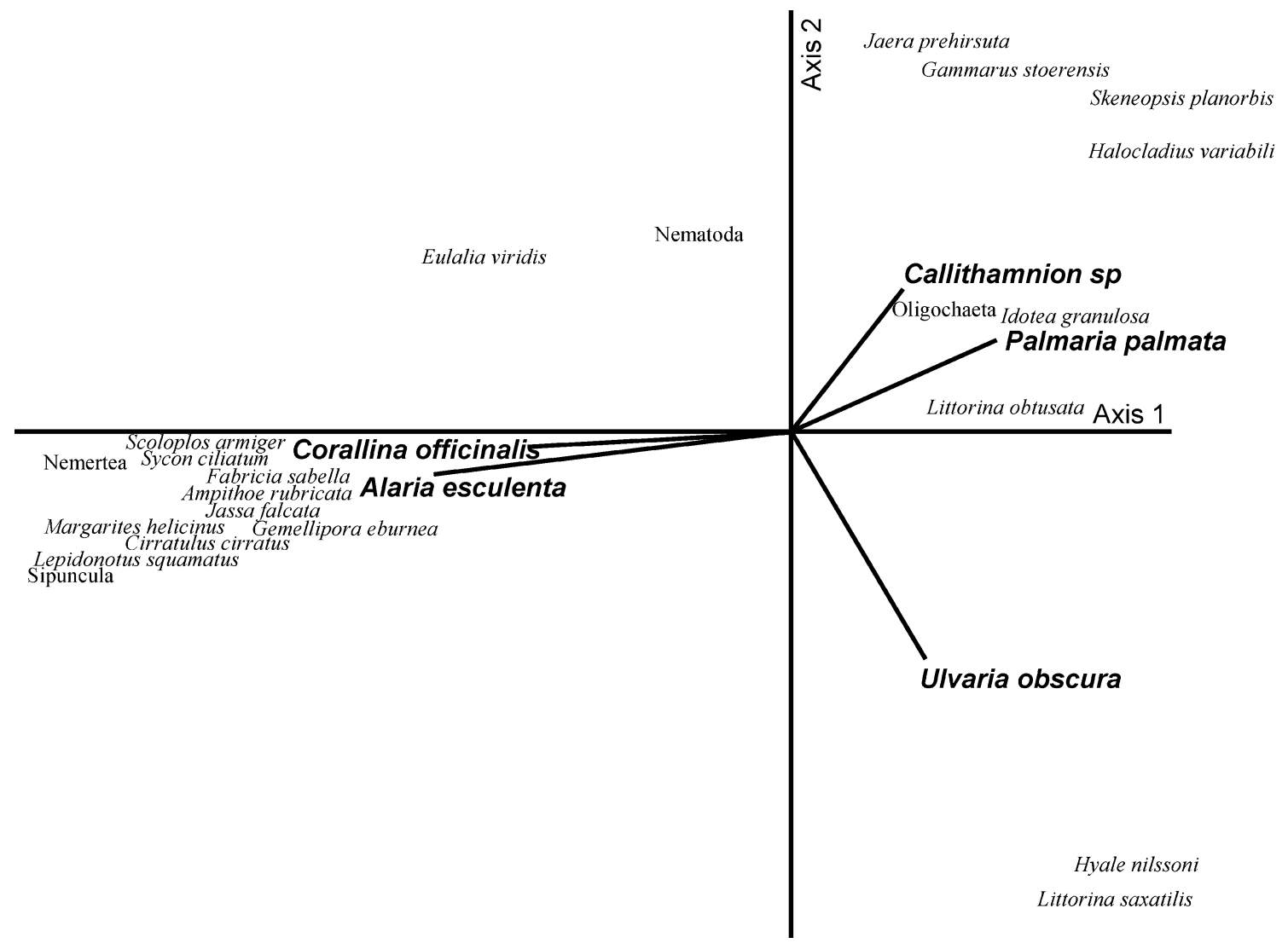

Fig. 10 Graph representation of the macrofaunal species and algae with respect to the first two axes of the CCA carried out for the Grimsey data on macrofaunal abundance and algal biomass; see also Table 5

Table 4 Results of the canonical correspondence analysis (Sandgerdi)

Only algae significantly correlated with CCA axis at $P<0.05$ are included

Table 5 Results of the Canonical Correspondence Analysis (Grimsey)

Only algae significantly correlated with CCA axis at $P<0.05$ are included

\begin{tabular}{llll}
\hline & Axis 1 & Axis 2 & Axis 3 \\
\hline Macrofauna-algae correlation & 0.86 & 0.84 & 0.90 \\
Percentage of species variance & 17.5 & 12.4 & 7.5 \\
Correlation with algae & & & 0.33 \\
Ascophyllum nodosum & - & -0.43 & - \\
Chondrus crispus & 0.58 & - & - \\
Corallina officinalis & 0.65 & -0.80 & 0.36 \\
Fucus serratus & - & - & 0.72 \\
Fucus vesiculosus & - & - & -0.51 \\
Mastocarpus stellatus & - & -0.32 & - \\
Palmaria palmata & - & - & - \\
Polysiphonia lanosa & - & - & - \\
Ulvaria obscura & 0.50 & & -0.57 \\
Laminaria digitata & 0.32 & &
\end{tabular}

\begin{tabular}{llll}
\hline & Axis 1 & Axis 2 & Axis 3 \\
\hline Macrofauna-algae correlation & 0.99 & 0.81 & 0.99 \\
Percentage of species variance & 40.6 & 11.5 & 9.3 \\
Correlation with algae & & & -47 \\
Callithamnion sp & - & - & -0.59 \\
Corallina officinalis & -0.77 & - & - \\
Fucus distichus & 0.45 & 0.54 & - \\
Palmaria palmata & - & -0.96 & - \\
Ulvaria obscura & 0.46 & - & - \\
Alaria sculenta & -0.49 & & \\
\hline
\end{tabular}




\section{References}

Albrecht A, Reise K (1994) Effects of Fucus vesiculosus covering intertidal mussel beds in the Wadden Sea. Helgoländer Meeresunters 48:243-256

Anderlini VC, Wear RG (1992) The effect of sewage and natural seasonal disturbances on benthic macrofaunal communities in Fitzroy Bay, Wellington, New Zealand. Mar Pollut Bull 24:21-26

Austen MC, Warwick RM, Rosado MC (1989) Meiobenthic and macrobenthic community structure along a putative pollution gradient in southern Portugal. Mar Pollut Bull 20:398-405

Ballantine WJ (1961) A biologically-defined exposure scale for the comparative description of rocky shores. Field Stud 1: 1-19

Bray JR, Curtis JT (1957) An ordination of the upland forest communities of Southern Wisconsin. Ecol Monogr 27:325-349

Clarke KR (1993) Non-parametric multivariate analyses of changes in community structure. Aust J Ecol 18:117-143

Clarke KR, Green RH (1988) Statistical design and analysis for a 'biological effects' study. Mar Ecol Prog Ser 46:213-226

Clarke KR, Gorley RN (2001) Primer (Plymouth Routines In Multivariate Ecological Research) v5: User Manual/Tutorial. PRIMER-E Ltd, Plymouth

Davenport J, Macalister H (1996) Environmental conditions and physiological tolerances of intertidal fauna in relation to shore zonation at Husvik, South Georgia. J Mar Biol Assoc UK 76:985-1002

Engledow HR, Bolton JJ (1994) Seaweed $\alpha$-diversity within the lower eulittoral zone in Namibia - the effects of wave action, sand inundation, mussels and limpets. Bot Mar 37:267-276

Field JG, Clarke KR, Warwick RM (1982) A practical strategy for analysing multispecies distribution patterns. Mar Ecol Prog Ser $8: 37-52$

Gunnarsson K, Ingólfsson A (1995) Seasonal changes in the abundance of intertidal algae in Southwestern Iceland. Bot Mar 38:69-77

Haahtela I (1984) A hypothesis of the decline of the bladder wrack (Fucus vesiculosus L.) in SW Finland in 1975-1981. Limnologica $15: 345-350$

Hansen JR, Ingólfsson A (1993) Patterns in species composition of rocky shore communities in sub-arctic fjords of eastern Iceland. Mar Biol 117:469-481

Ingólfsson A (1977). Distribution and habitat preferences of some intertidal amphipods in Iceland. Acta Naturalia Islandica 25:128

Ingólfsson A (1992) The origin of the rocky shore fauna of Iceland and the Canadian Maritimes. J Biogeogr 19:705-712

Ingólfsson A (1996) The distribution of intertidal macrofauna of the coasts of Iceland in relation to temperature. Sarsia 81:29-44

Jazdzewski K, De Broyer C, Pudlarz M, Dauby P (2001) Amphipods of a stony beach in maritime Antarctic. Polsk Arch Hydrob 47:569-577

Krauss W (1958) Temperatur, Salzgehalt und Dichte an der Oberfläche des Atlantischen Ozeans. Wiss Ergeb Deutsch Atl Exp "Meteor" 5:251-410

Leifsson BR (1998) Life cycles, breeding periods and vertical distribution of Idotea granulosa Rathke and I. pelagica Leach (Crustacea, Isopoda) on Icelandic shores. Sarsia 83:1-13

Lewis JR (1964) The ecology of rocky shores. English University Press, London

Littler MM, Kauker BJ (1984) Heterotrichy and survival strategies in the red alga Corallina officinalis L. Bot Mar 27:37-44

Littler MM, Murray SN (1975) Impact of sewage on the distribution, abundance and community structure of rocky intertidal macro-organisms. Mar Biol 30:277-291

Lopez-Gappa JJ, Tablado A, Magaldi NH (1990) Influence of sewage pollution on a rocky intertidal community dominated by the mytilid Brachidontes rodriguezi. Mar Ecol Prog Ser 63:163-175

Malmberg SA (1962) Schichtung und Zirkulation in den südisländischen Gewässern. Kieler Meeresforsch 18:3-28

McCune B, Mefford MJ (1997). PC-ORD. Multivariate analysis of ecological data. Mjm Software Design, Gleneden Beach

Munda IM (1972) General features of benthic algal zonation around the Icelandic coast. Acta Naturalia Islandica 21:1-34

Munda IM (1975) Hydrographically conditioned floristic and vegetation limits in Icelandic coastal waters. Bot Mar 18:223235

Munda IM (1976) The distribution of the Halosaccion ramentaceum (L). J. Agardh associations in Icelandic waters and their hydrographycally conditioned variations. Bot Mar 19:161-179

Munda IM (1977a) A comparison of the north and south European associations of Corallina officinalis L. Hydrobiologia 52:73-87

Munda IM (1977b) The structure and distribution of the Gigartina stellata (Stackh.) Batt. and Chondrus crispus Stackh. associations in Icelandic waters. Bot Mar 20:291-301

Munda IM (1977c) The benthic algal, vegetation of the island of Grimsey. Research Institute Nedri Ás Hveragerdi Iceland 28:169

Munda IM (1991) Shoreline ecology in Iceland, with special emphasis on the benthic algal vegetation. In: Mathieson AC, Nienhuis PHA (eds) Ecosystems of the world. Intertidal and littoral ecosystems. Elsevier Scientific Publications, Amsterdam, pp 67-81

Nicotri ME (1980) Factors involved in herbivore food preference. J Exp Mar Biol Ecol 42:13-26

Pielou EC (1966) The measurement of diversity in different types of biological collections. J Theor Biol 13:131-144

Raffaelli D, Hawkins S (1996) Intertidal ecology. Chapman and Hall, London

Sandulli R, De Nicola M (1991) Responses of meiobenthic communities along a gradient of sewage pollution. Mar Pollut Bull 22:463-467

Schreider MJ, Glasby TM, Underwood AJ (2003) Effects of height on the shore and complexity of habitat on abundances of amphipods on rocky shores in New South Wales. J Exp Mar Biol Ecol 293:57-71

Seapy RR, Littler MM (1978) The distribution, abundance, community structure, and primary productivity of macroorganisms from two central California rocky intertidal habitats. Pacific Sci32:293-314

Shannon CE, Weaver W (1963) The mathematical theory of communication. University of Illinois Press, Urbana

Sneath PHA, Sokal RR (1973) Numerical taxonomy. The principles and practice of numerical classification. WWH Freeman and Company, San Francisco

Stefánsson U (1962) North Icelandic waters. Rit Fiskideildar 3:1269

Stefánsson U (1969) Sjávarhiti á siglingalei umhverfis Ïsland. In: Einarsson MA (ed) Hafisinn. Almenna Bókafélagi, Reykjavík, pp 131-149

Ter Braak CJF (1990) Interpreting canonical correlation analysis through biplots of structure correlations and weights. Psychometrika 55:519-531

Underwood AJ, Chapman MG (1996) Subtidal assemblages on rocky reefs at a cliff-face sewage outfall (North Head, Sydney, Australia): what happened when the outfall was turned off? Mar Pollut Bull 33:293-302

Warwick RM (1986) A new method for detecting pollution effects on marine macrobenthic communities. Mar Biol 92:557-562

Warwick RM, Pearson TH, Ruswahyuni H (1987) Detection of pollution effects on marine macrobenthos: further evaluation of the species abundance/biomass method. Mar Biol 95:193-200

Williams GA (1990) Littorina mariae - a factor structuring low shore communities. Hydrobiologia 193:139-146 